\title{
MICROSTRUCTURAL AND THERMAL STABILITY OF SELECTIVE LASER MELTED 316L STAINLESS STEEL SINGLE TRACKS\#
}

\author{
P. Krakhmalev ${ }^{1}$, I. Yadroitsava², G. Fredriksson ${ }^{1} \&$ I. Yadroitsev²*
}

\section{ARTICLE INFO}

\section{Article details}

Submitted by authors 12 Jan 2016 Accepted for publication 7 Dec 2016 Available online 26 May 2017

\# This is an extended version of a paper presented at the 16th annual RAPDASA international

conference, held in Pretoria, South Africa.

\section{Contact details}

Corresponding author

iyadroitsau@cut.ac.za

Author affiliations

1 Department of Engineering and Physics, Karlstad University, Sweden

2 Department of Mechanical and Mechatronic Engineering, Central University of Technology, South Africa

\section{DOI}

http://dx.doi.org/10.7166/28-1-1466

\section{ABSTRACT}

To remove residual stresses, an as-built SLM object is usually posttreated. This treatment can affect the microstructure, changing the final mechanical characteristics. This investigation is focused on the microstructural characterisation of $316 \mathrm{~L}$ austenitic stainless steel in as-built and annealed conditions. The SLM microstructure was relatively stable up to $900^{\circ} \mathrm{C}$, when cell boundaries start to disappear. At higher temperatures, an insignificant grain coarsening was detected. These microstructural changes caused a gradual drop in the hardness. The obtained result is background for the future development of post-treatment regimens to achieve a high level in the final mechanical properties of SLM objects.

\section{OPSOMMING}

Om die res-spannings in ' $\mathrm{n}$ lasergesinterde metaalvoorwerp te verwyder, word die voorwerp gewoonlik na die tyd behandel. Hierdie behandeling kan die mikrostruktuur beïnvloed, wat kan lei tot ' $n$ verandering in die meganiese eienskappe. Hierdie ondersoek fokus op die mikrostruktuur karakterisering van 316 austenitiese vlekvrye staal in die soos-vervaardige en uitgegloeide toestande. Die lasergesinterde metaal mikrostruktuur was relatief stabiel tot $900^{\circ} \mathrm{C}$, waarna alle selgrense begin verdwyn het. By hoër temperature is onbeduidende grein vergrowwing bespeur. Hierdie mikrostruktuur veranderinge veroorsaak 'n geleidelike afname in die hardheid van die voorwerp. Dié resultaat skep die basis vir verdere ontwikkeling van die behandeling skedules om 'n hoë vlak in die finale meganiese eienskappe van lasergesinterde metaalvoorwerpe te verkry.

\section{INTRODUCTION}

The direct industrial applicability of parts and components manufactured by selective laser melting (SLM) is a challenge because the final objects have a non-conventional microstructure, a high level of residual stresses, and a set of mechanical properties different from standards. For these reasons, a post-treatment of objects manufactured by SLM is often required [1,2]. For instance, a stress relieving heat treatment is used for surgery implants to achieve geometrical tolerance and to remove stresses.

The microstructure of steel objects manufactured by SLM is different from conventional cast or wrought material. SLM steels solidify with a formation of colonies of coherent cells [3]. This microstructure usually demonstrates higher hardness and strength characteristics than the conventional materials, due to fine structure and residual stresses. To remove residual stresses, stress-relieving heat treatment is often used. At temperatures used for relieving stress, diffusional and relaxation processes start. Those diffusional processes can initiate changes in the dislocation structures, polygonisation, annihilation of dislocations and, eventually, the grain growth. These processes are usually accompanied by a remarkable change of mechanical properties, softening, and an increase in ductility. 
Since heat treatment can cause desirable stress relief, undesirable softening, and grain coarsening effects, it is important to study those processes. This investigation is focused on a characterisation of the microstructure of AISI 316L austenitic stainless steel. This steel is an important material, found in high-temperature, chemical, and medical applications. The SLM-manufactured single tracks of AISI 316L steel were investigated in as-built conditions, and then isothermally heat-treated in a temperature range typical for the stress-relieving heat treatment of conventionally-manufactured material. Observed microstructural changes were analysed and discussed in correlation with changes in hardness of the material. The results aimed to benefit the development of heat treatment regimes to achieve the required combination of microstructure and properties.

\section{MATERIALS AND METHODS}

Sandvik Osprey Ltd gas-atomised spherical powders were used in the experiments. The chemical composition of the powder, according to the supplier, is shown in Table 1; the powder morphology is shown in Figure 1(a). The powder had the equivalent particle diameters $d_{10}=4.6 \mu \mathrm{m}, d_{50}=13.0 \mu \mathrm{m}$ and $d_{90}=27.5 \mu \mathrm{m}$ (wt\% by volume). The particle size distribution was estimated with the optical granulo-morphometer OCCHIO Alpaga 500 Nano. The powders were dried at $80^{\circ} \mathrm{C}$ for 12 hours.

Table 1: Chemical composition of powder and substrate

\begin{tabular}{|l|l|l|l|l|l|l|l|l|l|}
\hline Material & \multicolumn{7}{|c|}{ Chemical composition in wt\% } \\
\cline { 2 - 10 } & $\begin{array}{l}\text { C, } \\
\text { max. }\end{array}$ & $\begin{array}{l}\text { Mn, } \\
\text { max. }\end{array}$ & $\begin{array}{l}\text { P, } \\
\text { max. }\end{array}$ & $\begin{array}{l}\text { S, } \\
\text { max. }\end{array}$ & $\begin{array}{l}\text { Si, } \\
\text { max. }\end{array}$ & Cr & Ni & Mo & Fe \\
\hline $\begin{array}{l}\text { AISI 316L } \\
\text { powder }\end{array}$ & 0.030 & 2.00 & 0.045 & 0.030 & 1.00 & $16.00-18.00$ & $10.00-14.00$ & $2.00-3.00$ & Bal. \\
\hline $\begin{array}{l}\text { AISI 304 } \\
\text { substrate }\end{array}$ & 0.030 & 2.00 & 0.045 & 0.030 & 1.00 & $18.00-20.00$ & $8.00-12.00$ & 0.00 & Bal. \\
\hline
\end{tabular}

The SLM experiments were carried out using a single-mode continuous-wave Ytterbium fibre laser operating at $1075 \mathrm{~nm}$ wavelength. The process chamber was a closed environment filled by nitrogen as a protective gas. The laser beam had a TEM00 Gaussian profile, $70 \mu \mathrm{m}$ spot size, and $200 \mathrm{~W}$ maximum power. Single tracks were manufactured on the AISI 304 steel substrate. A set of tests was done to select the proper SLM parameters to fabricate tracks for the future investigation of thermal stability and corrosion behaviour.

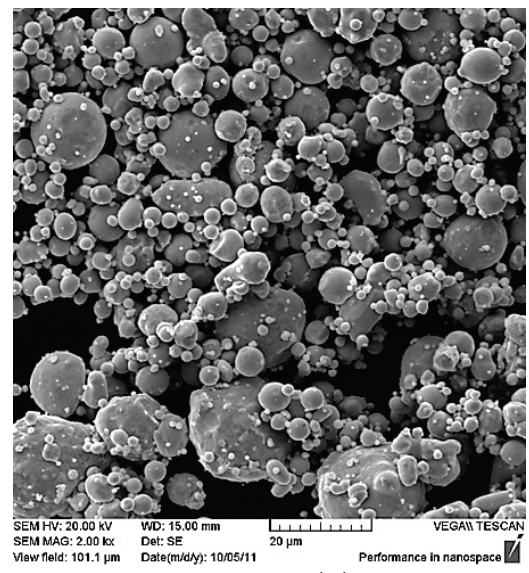

(a)

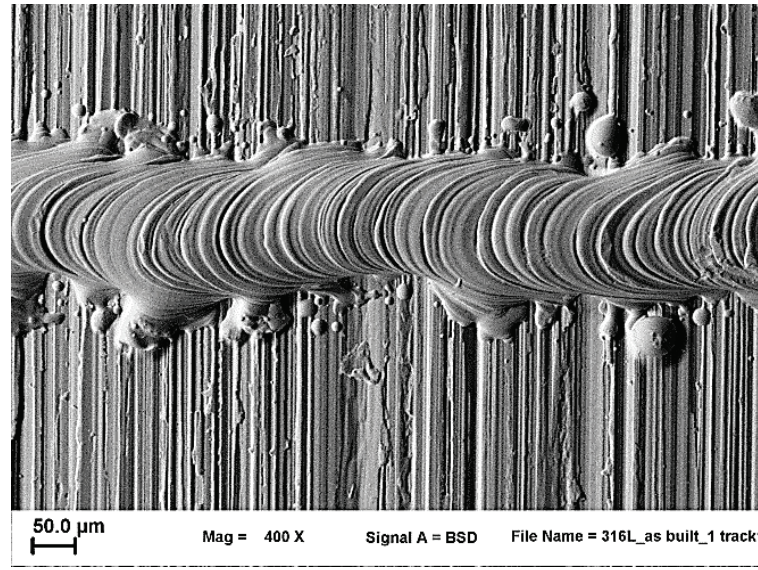

(b)

Figure 1: (a) Morphology of the used powder of AISI 316L austenitic stainless steel, and (b) top view of the manufactured track

To investigate the thermal stability of the microstructure and its corrosion behaviour, the manufactured specimens were annealed in the furnace for 15 minutes at $450-1050^{\circ} \mathrm{C}$ (interval of $50^{\circ} \mathrm{C}$ ) without protective atmosphere. Cross-sections of the SLM samples were subjected to a standard metallographic procedure. The measurements of microhardness were done in accordance with ISO 6507 under $50 \mathrm{~g}$ load using a BUEHLER MHT 5104 microhardness tester. Electron microscopy was carried out with a LEO 1350 FEG-SEM at 20kV accelerating voltage and JEOL (JEM 2100) TEM 
with a LaB6 cathode. Energy dispersive X-ray spectroscopy (EDX analysis) was done with an Oxford Instruments INCAX-sight EDX detector.

\section{RESULTS AND DISCUSSION}

Manufacturing of consistent and high-quality single tracks is one of the conditions influencing the high quality of the final object [4]. A number of investigations were dedicated to optimisation and statistical analysis of the laser parameters that would result in tracks without the balling effect, having good metallurgical bonding to the substrate, and consistent geometrical characteristics [58]. The usual morphology of the single track is shown in Figure 1(b). Since the substrate and the powder had different chemical compositions, an EDX analysis was done to make sure that the composition of the tracks was homogeneous. Figure 2 shows EDX MoL1a maps of two tracks fabricated with different sets of laser parameters. In Figure 2(a) it is clearly visible that there is a segregation of $\mathrm{Mo}$ in the central regions of the track made at $80 \mathrm{~mm} / \mathrm{s}$. Optimisation of the manufacturing parameters - in this case, an increase in the laser scanning speed - resulted in improved chemical homogeneity within the track.

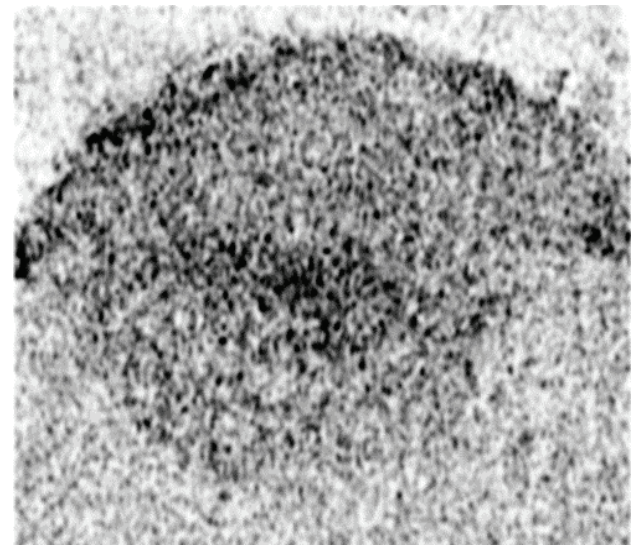

(a)

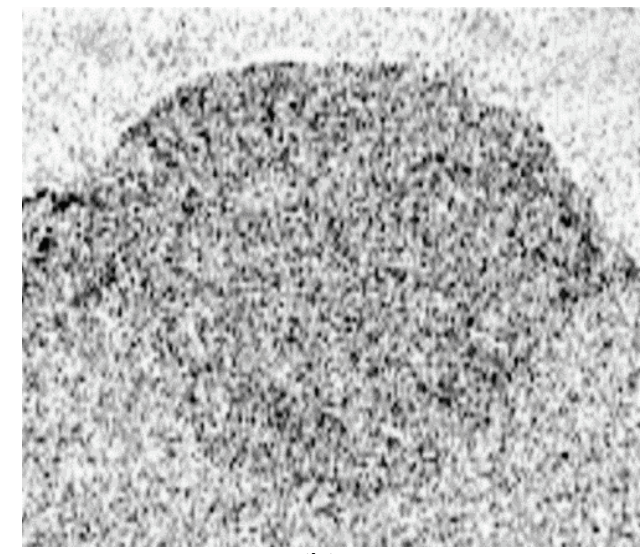

(b)

Figure 2: Mol1a maps of two tracks fabricated (a) at $80 \mathrm{~mm} / \mathrm{s}$ and (b) at $240 \mathrm{~mm} / \mathrm{s}$ laser scanning speeds, with laser power at $50 \mathrm{~W}$

The dynamics of the liquid phase in the molten pool were complicated, as many factors could contribute to the mass transport. Among them, convection, Marangoni flows, and local density gradients were the most important [9]. These processes influenced the chemical homogeneity and stability of the tracks [10]. Therefore, to fabricate a homogeneous and continuous track, a tradeoff set of parameters should be used. This investigation used the following set of SLM parameters: laser power $P=50 \mathrm{~W}$, laser scanning speed $V=0.12 \mathrm{~m} / \mathrm{s}$, powder layer thickness $h=70 \mu \mathrm{m}$. This was found to be optimal; thus, for further investigations, the tracks were manufactured with this set of parameters.

The microstructure of AISI 316 steel manufactured by SLM in as-built conditions was thoroughly investigated and described. It has been shown that the tracks consist of colonies of coherent cells, which are clearly visible with an electron microscope. These features are typical for single tracks and for 3D objects made of AISI 316L steel [3,11]. The cell boundaries were confirmed to be the dislocation structures [11-12] that influenced the strength characteristics of the SLM objects. The colonies nucleated epitaxially at the substrate and inherited the crystallographic orientation of the parental grains [9].

It has been shown $[3,13]$ that the colony growth direction depends on the laser scanning parameters and position within the track. The crystallographic orientation of a colony also influences the crystallisation direction and rate. For cubic crystal systems, the $\langle 100\rangle$ crystallographic orientation was found to be a preferable crystallisation direction. Therefore the colonies growing in the $\langle 100\rangle$ crystallographic orientation dominated in the competitive growth [9, 13-15]. This crystallographic texture was found in solidified welds of various steels, and was also reported for $\mathrm{Ni}$ and $\mathrm{Co}$ superalloys. In the case of laser remelting or laser cladding of single-crystal superalloys, the 
crystallographic relationship plays an important role, contributing to the dendrite growth rate and direction - i.e., the texture in the remelted material or clad [13-15].

Since a post-treatment is often required for SLM objects, thermally-activated processes will influence the microstructure and so affect the final properties of the material. The post-treatment, such as stress relief, for $316 \mathrm{~L}$ steel is done at temperatures of $900^{\circ} \mathrm{C}$ or above [16]. At these temperatures the recovery and even the recrystallisation can take place. Analysis of the microstructures before and after annealing showed that several microstructural changes occurred after the heat treatment. Firstly, the cells disappeared at temperatures around $900^{\circ} \mathrm{C}$, and secondly, some grain coarsening occurred at temperatures of $950^{\circ} \mathrm{C}$ and above. Oxidation of the top region of the tracks also began at $700-750^{\circ} \mathrm{C}$, and developed remarkably at higher temperatures in the heat treatment (Figure 3).

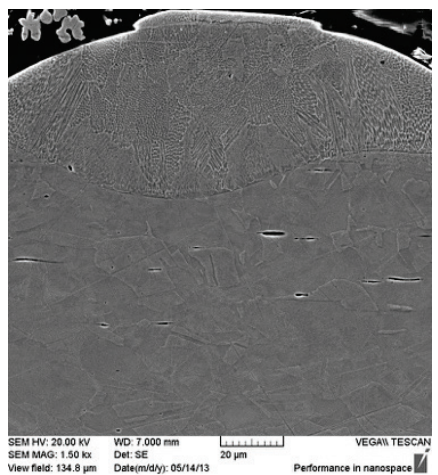

(a)

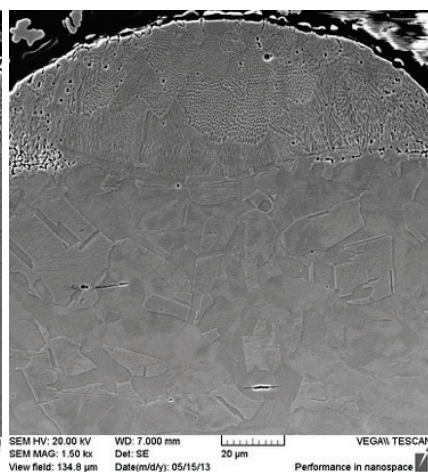

(b)

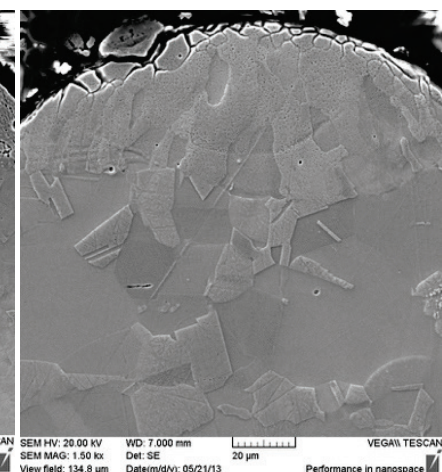

(c)

Figure 3: Cross sections of tracks in (a) as-built and annealed conditions: at (b) $750^{\circ} \mathrm{C}$ and (c) $1000^{\circ} \mathrm{C}$

The behaviour of dislocations at elevated temperatures is controlled by the recovery processes and involves interaction, annihilation, and non-conservative movement of the dislocations. Very similar processes control the evolution of the cellular structures in the SLM material. Analysis of the cell size measured in the SEM shows that the size was relatively stable up to temperatures of $800-850^{\circ} \mathrm{C}$ (Figure 4).

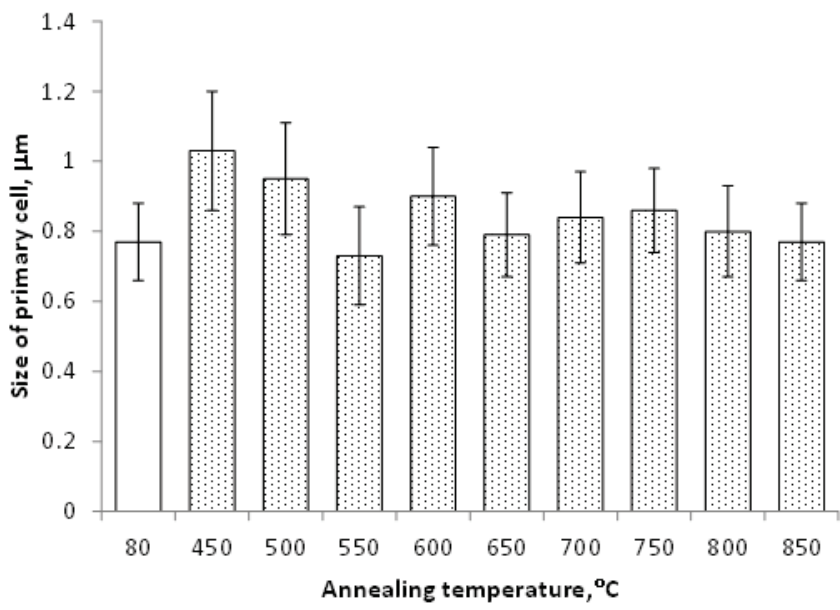

Figure 4: Evolution of primary cell size in relation to the heat treatment temperature

These observations confirm that the enhanced hardness and strength values, commonly reported in as-built SLM objects [3, 11], are related to increased dislocation density. Even though the dislocations form specific structures and cell boundaries, they contribute to the strengthening of the material. Obviously, the dislocation density will be higher in a material with finer primary cell size - i.e., material containing more cell walls per unit volume. This can also explain the fairly large spread in hardness and strength values reported in the literature. The cell size is very sensitive to 
the crystallisation rates [17], which are different for different laser-assisted processes and equipment. The situation is even more complicated, since the cell size is not a constant within even a single track and, of course, it varies with changes in the laser power, the laser scanning speed, and other manufacturing parameters [3].

Annealing at temperatures higher than $900^{\circ} \mathrm{C}$ resulted in the complete disappearance of cell structures, and the beginning of processes similar to grain coarsening. Nevertheless, analysis showed that, even after heat treatment for 15 minutes at $1050^{\circ} \mathrm{C}$, grains had not coarsened dramatically. At the same time, significant grain coarsening could be observed in the substrate. This indicated a fairly high stability of the colony boundaries formed directly from the liquid during fabrication. In comparison with the recrystallisation and grain coarsening observed in the nanograined 316L material [18-19], the SLM microstructure seems to have been more stable. In the work of Zhao et al. [18], grain coarsening was already observed at temperatures of $700-800^{\circ} \mathrm{C}$, and the grains were found to be twice as big after the temperature in the 15 minutes of isothermal treatment had been raised from 800 to $950^{\circ} \mathrm{C}$. Similarly, Yan et al. [19] reported a doubling of the coarser grains in nanocrystalline $316 \mathrm{~L}$ steel after 20 minutes at $750^{\circ} \mathrm{C}$. These differences could be a result of the different nature of the boundaries. In the nanocrystalline materials obtained by plastic deformation, the boundaries were formed by an interaction of mobile dislocations with each other and with microstructural defects. In the SLM material formed at solidification, the cell boundaries could instead be sessile dislocations, or be a relatively immobile dislocation structure with a number of jogs and kinks. At the elevated temperatures, the dislocations can reveal conservative (glide) and non-conservative (climb or cross-slip) mobility. The immobile boundaries formed at the solidification can only move non-conservatively - i.e., they show higher stability and annihilate later.

It can be seen that the microhardness changes from 280 to $230-220 \mathrm{HV}$ after heat treatment at temperatures of $800-900^{\circ} \mathrm{C}$ (Figure 5). A comparison with the behaviour of the cell size shows that, after heat treatment at these temperatures, the cell size does not change remarkably. Some observed decrease in the hardness could be explained by stress relief at the elevated temperatures. Residual stresses in the as-built SLM objects have been actively investigated in recent years [20-21], and have shown that in the as-built state the stress values reached 300-800 MPa. Relief of those stresses at temperatures up to $900^{\circ} \mathrm{C}$ could result in some decrease in hardness. A significant drop in the hardness values was observed as cell boundaries began to disappear. Figure 6 shows changes in dislocation density and structures in the steel before and after annealing. The changes are similar to other reported observations [12, 22].

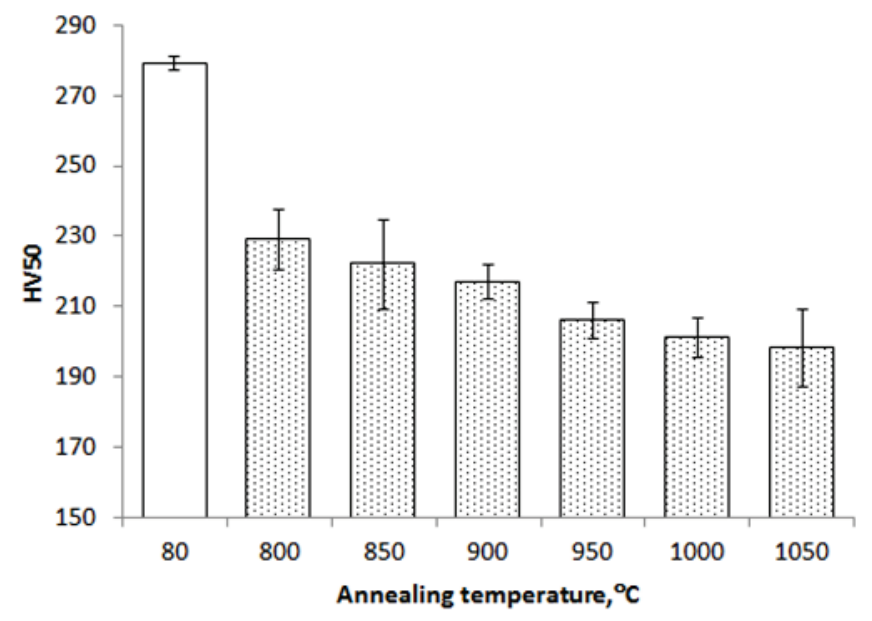

Figure 5: $\mathrm{HV}_{50}$ microhardness values in relation to the heat treatment temperature

A side-effect of the heat treatment carried out in the oxidative air environment was surface oxidation of the specimens. Depending on the temperature, the most common mechanisms of corrosion reported in $316 \mathrm{~L}$ steel are formation of an oxide scale or an intergranular corrosion. A protective chromium oxide scale is formed on the surface at relatively low temperatures, and stays stable until test temperatures rise above $800^{\circ} \mathrm{C}$. Formed at higher temperatures, the scale is enriched with iron, and the oxide scale is no longer protective. In addition, at high temperatures a 
scale breakdown can happen [23]. Another oxidation mechanism is intergranular corrosion, which is usually related to the grain boundary precipitation of chromium-rich intermetallic particles, and thus chromium depletion in the adjacent areas [24-25].

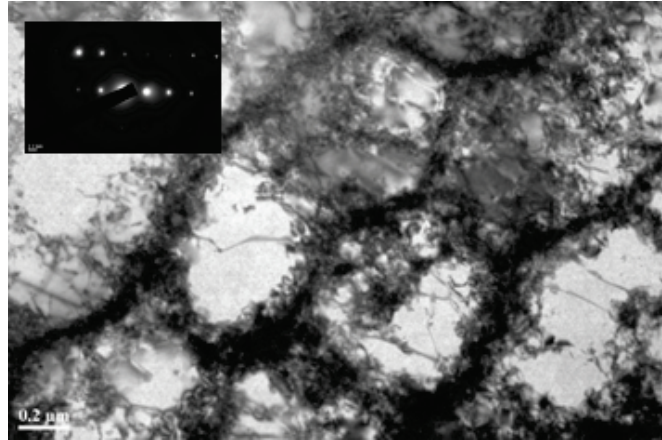

(a)

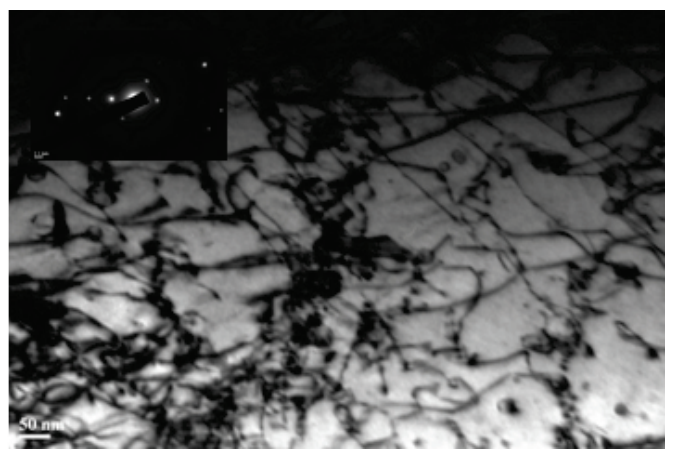

(b)

Figure 6: Bright field TEM image of the dislocation structures observed in (a) the as-built [12] and (b) annealed 316L steel fabricated by SLM

In the investigated single tracks of $316 \mathrm{~L}$ material, the first grain boundary corrosion was observed after 15 minutes at $700^{\circ} \mathrm{C}$, and it developed noticeably at higher temperatures (Figure 7). Analysis of the etched cross-sections showed that the selective oxidation along the colony boundaries was observed at the temperatures when the cells still existed. This is an interesting observation: in principle, cell boundaries are highly defected regions, and might be an easy path for oxygen to penetrate into the bulk. The SEM EDX analysis, nevertheless, did not reveal any non-homogeneities along the grain boundaries, neither before nor after annealing. This might be a result of the EDS method resolution, or of the extremely fine size of the precipitations. Nevertheless, the experimental observations prove that intergranular corrosion was the main mechanism causing the surface degradation after annealing for 15 minutes at temperatures above $700^{\circ} \mathrm{C}$.

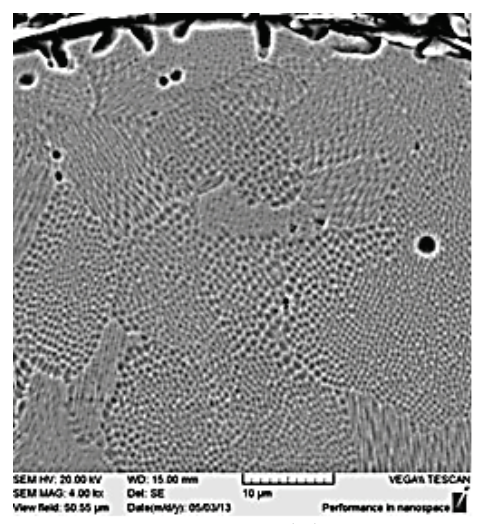

(a)

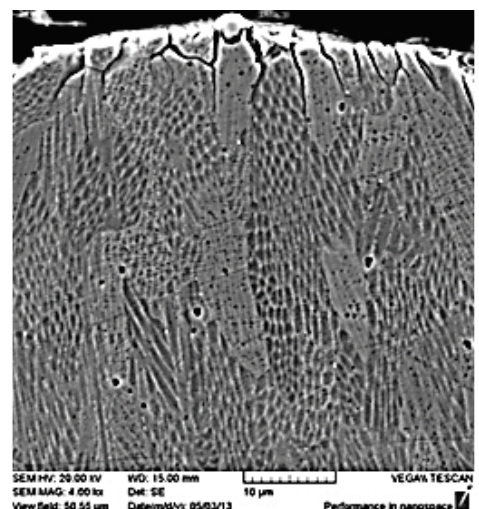

(b)

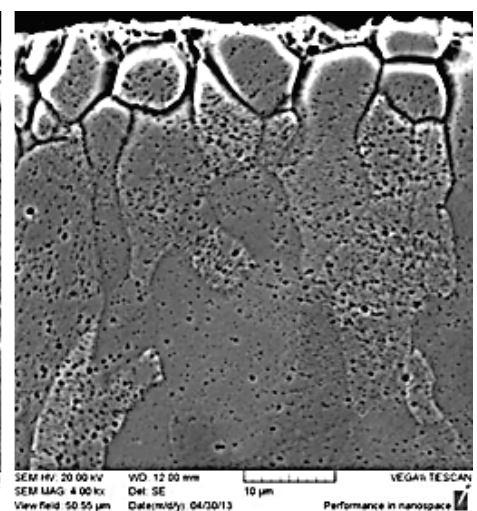

(c)

Figure 7: Depth of intergranular corrosion after 15 minutes annealing at (a) $750^{\circ} \mathrm{C}$, (b) $850^{\circ} \mathrm{C}$, and (c) $1050^{\circ} \mathrm{C}$

\section{CONCLUSIONS}

The as-built microstructure of the single tracks fabricated of $316 \mathrm{~L}$ austenitic stainless steel consists of colonies of coherent cells. A microhardness of $280 \mathrm{HV}$ in the as-built condition was measured.

The microstructure was relatively stable, and modified in several steps with heat treatment. At temperatures below $900^{\circ} \mathrm{C}$, some decrease in microhardness was observed, possibly due to residual stress relaxation. The first microstructural changes took place at temperatures of about $900^{\circ} \mathrm{C}$. At these temperatures the cell boundaries were annihilated, as shown by SEM observations. At temperatures above $900^{\circ} \mathrm{C}$, grain coarsening was observed. This grain coarsening led to a drop in the microhardness to values of $195 \mathrm{HV}$. 
The main surface damage mechanism of single tracks after heat treatment at air atmosphere was grain boundary corrosion. Selective oxidation was observed along the colony boundaries; highlydefected cell boundaries seemed to have no enhancing effect on the selective oxidation. The first traces of the colonies' boundary corrosion were detected at $700^{\circ} \mathrm{C}$, and selective oxidation developed with an increase in temperature.

\section{ACKNOWLEDGEMENTS}

Part of this work is based on research supported by the South African Research Chairs Initiative of the Department of Science and Technology and the National Research Foundation of South Africa (Grant № 97994) and the Collaborative Program in Additive Manufacturing (Contract № CSIR-NLCCPAM-15-MOA-CUT-01).

\section{REFERENCES}

[1] Chlebus, E., Gruber, K., Kuźnicka, B., Kurzac, J. \& Kurzynowski, T. 2015. Effect of heat treatment on the microstructure and mechanical properties of Inconel 718 processed by selective laser melting, Materials Science and Engineering A, 639, pp 647-655.

[2] Prashanth, K.G., Scudino, S., Klauss, H.J., Surreddi, K.B., Löber, L., Wang, Z., Chaubey, A.K., Kühn, U. \& Eckert, J. 2014. Microstructure and mechanical properties of Al-12Si produced by selective laser melting: Effect of heat treatment, Materials Science and Engineering A, 590, pp 153-160.

[3] Yadroitsev, I., Krakhmalev, P., Yadroitsava, I., Johansson, S. \& Smurov, I. 2013. Energy input effect on morphology and microstructure of selective laser melting single track from metallic powder, Journal of Materials Processing Technology, 213(4), pp 606-613.

[4] Yadroitsev, I., Krakhmalev, P. \& Yadroitsava, I. 2015. Hierarchical design principles of selective laser melting for high quality metallic objects, Additive Manufacturing, 7(15), pp 45-56.

[5] Yadroitsev, I. 2009. Selective laser melting: Direct manufacturing of 3D-objects by selective laser melting of metal powders, LAP Lambert Academic Publishing AG \& Co KG.

[6] Yadroitsev, I., Yadroitsava, I., Bertrand, Ph. \& Smurov, I. 2012. Factor analysis of selective laser melting process parameters and geometrical characteristics of synthesized single tracks, Rapid Prototyping Journal, 18(3), pp 201-208.

[7] Sun, J., Yang, Y. \& Wang, D. 2013. Parametric optimization of selective laser melting for forming Ti6Al4V samples by Taguchi method, Optics \& Laser Technology, 49, pp 118-124.

[8] Casalino, G., Campanelli, S.L., Contuzzi, N. \& Ludovico, A.D. 2015. Experimental investigation and statistical optimisation of the selective laser melting process of a maraging steel, Optics \& Laser Technology, 65, pp 151-158.

[9] Kou, S. 2003. Welding metallurgy, 2nd edition, New Jersey: Wiley-Interscience.

[10] Yadroitsev, I., Gusarov, A., Yadroitsava, I. \& Smurov I. 2010. Single track formation in selective laser melting of metal powders, Journal of Materials Processing Technology, 210(12), pp 1624-1631.

[11] Saeidi, K., Gao, X., Zhong, Y. \& Shen, Z.J. 2015. Hardened austenite steel with columnar sub-grain structure formed by laser melting, Materials Science and Engineering A, 625, pp 221-229.

[12] Krakhmalev, P., Yadroitsava, I., Fredriksson, G. \& Yadroitsev, I. 2014. Microstructure of SLM manufactured 316L and 420 grades stainless steel. In: Proceeding of the RAPDASA 15th Annual International Conference, 6-7 November 2014, Stellenbosch, South Africa, pp 59-66.

[13] Hemmati, I., Ocelik, V. \& DeHosson, J.T.M. 2010. Microstructure and properties of laser clad coatings studied by orientation imaging microscopy, Acta Materialia, 58(20), pp 6763-6772.

[14] Gaumann, M., Henry, S., Cleton, F., Wagniere, J.D. \& Kurz, W. 1999. Epitaxial laser metal forming: Analysis of microstructure formation, Materials Science and Engineering A, 271(1-2), pp 232-241.

[15] Yang, S., Huang, W., Liu, W., Zhong, M. \& Zhou, Y. 2002. Development of microstructures in laser surface remelting of DD2 single crystal, Acta Materialia, 50(2), pp 315-325.

[16] Davis, J.R. (ed.) 1994. ASM Specialty Handbook: Stainless steels, Materials Park, OH: ASM International.

[17] Kurz, W. \& Trivedi, R. 1994. Rapid solidification processing and microstructure formation, Materials Science and Engineering A, 179-180, pp 46-51.

[18] Zhao X., Liu, Y. Wang, Y., Feng, P. \& Tang, P. 2014. Recrystallization and grain growth of 316L stainless steel wires, Metallurgical and Materials Transactions A, 45(8), pp 3446-3453.

[19] Yan, F.K., Liu, G.Z., Tao, N.R. \& Lu, K. 2012. Strength and ductility of 316L austenitic stainless steel strengthened by nano-scale twin bundles, Acta Materialia, 60(3), pp 1059-1071.

[20] Furumoto, T., Ueda, T., Abdul Aziz M.S., Hosokawa, A. \& Tanaka, R. 2010. Study on reduction of residual stress induced during rapid tooling process: Influence of heating conditions on residual stress, Key Engineering Materials, 447-448, pp 785-789.

[21] Vrancken, B., Cain, V., Knutsen, R. \& Van Humbeeck, J. 2014. Residual stress via the contour method in compact tension specimens produced via selective laser melting, Scripta Materialia, 87, pp 29-32.

[22] Saeidi, K., Lofaj, F., Kvetkova, L. \& Shen, Z.J. 2015. Transformation of austenite to duplex austeniteferrite assembly in annealed stainless steel $316 \mathrm{~L}$ consolidated by laser melting, Journal of Alloys and Compounds, 633, pp 463-469. 
[23] Habib, K.A., Damra, M.S., Saura, J.J., Cervera, I. \& Bellés, J. 2011.Breakdown and evolution of the protective oxide scales of AISI 304 and AISI 316 stainless steels under high-temperature oxidation, International Journal of Corrosion, 2011, pp 1-10.

[24] Sahlaoui, H., Makhlouf, K., Sidhom, H. \& Philibert, J. 2004. Effects of ageing conditions on the precipitates evolution, chromium depletion and intergranular corrosion susceptibility of AISI 316L: Experimental and modeling results, Materials Science and Engineering A, 372(1-2), pp 98-108.

[25] Matula, M., Hyspecka, L., Svoboda, M., Vodarek, V., Dagbert, D., Galland, J., Stonawska, Z. \& Tuma, L. 2001. Intergranular corrosion of AISI 316L steel, Materials Characterization, 46(1-2), pp 203-210. 